\title{
FUSARIUM WILT OF CANARY ISLAND DATE PALMS
}

\author{
L.V. GUNN and B.A. SUMMERELL \\ Royal Botanic Gardens, Mrs Macquaries Rd, Sydney, \\ New South Wales 2000, Australia
}

\begin{abstract}
Fusarium wilt caused by Fusarium oxysporum f.sp. canariensis has caused the death of hundreds of Canary Island date palms, Phoenix canariensis, in Sydney where they have been used prominently in landscape plantings. The fungus is spread in soil, by transplanting palms and on contaminated pruning implements and possibly by seed, birds and insects. Vegetative compatibility groupings (VCGs) were used to examine the diversity and population structure of over 70 isolates of F. oxysporum f.sp. canariensis collected from different sites and different parts of individual palms within a site. Compatibility groupings showed two major VCGs limited to one site and a scattering of smaller VCGs throughout the Sydney region. Typically, frond isolates from the one site fitted into the one group while non-frond isolates (roots, soil and fruit) did not. A low proportion of seed isolates were compatible with the major (and presumably pathogenic) group, indicating seed transmission of the disease is possible. PCR analysis using primers designed to amplify the pathogenic group is in progress to both confirm VCG groupings and develop a rapid diagnostic test for the disease.

Keywords: Fusarium oxysporum, Fusarium wilt, palms, Phoenix spp.
\end{abstract}

\section{INTRODUCTION}

Fusarium wilt is a devastating disease of certain species of palms. The disease was first observed in Australia in the early 1980s when palms began to die at Centennial Park in Sydney (Priest and Letham 1996). The disease is also found in the USA (Simone and Cashion 1996), France (Mercier and Louvet 1973), Canary Islands and Japan (Arai and Yamagoto 1977). Since that time the disease has caused the death of most of the Phoenix palms in Centennial Park. Since the initial infections, the disease has been observed in a number of locations in central and suburban Sydney. This is of concern because Phoenix canariensis was widely planted throughout Australia, particularly in the first three decades of this century and they are an important part of the horticultural heritage in many Australian cities and rural towns.

Palms affected by this disease are characterised by death of fronds which is distinct from normal. Fronds may die more rapidly on one side of affected trees or more rapidly from the bases or centres of the trees. Most characteristically, lower fronds die rapidly so that eventually only a few surviving fronds form spikes at the tops of the trees. When individual fronds are examined, on one side the pinnae and spines are often dead while the other side is alive. Eventually affected palms will die. Affected fronds will often show discolouration of the vascular bundles.

The disease is caused by a fungus, Fusarium oxysporum. This pathogen has many different strains that cause wilt diseases in a range of plants but each strain is restricted to a limited host range. Non-pathogenic strains of $F$. oxysporum are ubiquitous in soils. These strains cannot be differentiated from the pathogenic strains by morphological features, so it is not possible to test soils for the presence of pathogenic strains prior to or after planting using morphological characteristics for identification.

Although the symptoms of Fusarium wilt are quite distinctive, in many cases the disease can only be accurately diagnosed by laboratory tests where sections of the frond are plated onto agar and the fungus grown out. Pure cultures of the fungus are

Proc. 52nd N.Z. Plant Protection Conf. 1999: 29-31 
grown on specified media which allow identification. Identification of Fusarium species requires specialised training. As no satisfactory soil test exists for $F$. oxysporum, a molecular technique for identification of pathogenic strains of the fungus would be very useful. Such a technique was developed by Plyler et al. (1998) in Florida USA; we have adapted this technique to Australian isolates and compared results to studies using vegetative compatibility analysis to determine aspects of the genetic makeup of the fungus in Sydney.

\section{METHOD}

Isolates of $F$. oxysporum $\mathrm{f}$. sp. canariensis were obtained from a number of sites in the eastern and inner western suburbs of Sydney by plating frond rachis sections on peptone PCNB agar (Burgess et al. 1994). Two parks, each with a number of infected palms, were sampled intensively with ten palms sampled in Burwood Park (fronds only) and seven palms in Bexley Park (fronds, roots, soil, seed and seed coats). Isolates were also supplied by NSW Agriculture disease herbarium (Priest and Letham 1996) and a collection of isolates from Canary Islands, Florida, California and Japan by Dr H.C. Kistler, University of Florida.

Vegetative compatibility groupings were based on the method developed by Puhalla (1985). Sixty isolates were selected for VCG testing. Spontaneous nitrate nonutilising (nit) mutants were generated on chlorate medium, characterised as nit 1, nit 3 or NitM and complemented on minimal medium. Heterokaryon formation was evident by the appearance of a wild type mycelium at the contact zone between two nit mutants.

Isolates for PCR amplification were grown in liquid medium and DNA extracted using the FastPrep protocol (Integrated Sciences). PCR was carried out on $2 \mu \mathrm{L}$ of the product using the primers and protocol of Plyler et al. (1999). A 567 bp product resulted in the positive reactions while no bands were detected in the negative reactions. Eighty five isolates were used for PCR testing; sixty originally used for VCG analysis and the remainder additional samples from Bexley Park.

\section{Vegetative compatibility groups}

\section{RESULTS}

There were two major vegetative compatibility groups (VCGs), with all Burwood isolates in one group and all frond isolates and some non-frond isolates from Bexley in the other. There were four other groupings with more than one member but their distribution appeared random. The remainder of the isolates either reacted only with themselves or were heterokaryon self-incompatible. Many isolates were difficult to place into groups as they were either unstable or bridging isolates.

Using this technique to "map" the parts of the palm where pathogenic isolates are located proved to be difficult. Sections of frond rachis from affected trees usually yielded a high proportion of $F$. oxysporum isolates, however sections from all other parts only rarely, and sometimes never produced $F$. oxysporum. This limited the number available for testing. Results showed all 15 isolates from fronds to be in the one group with one seed isolate (out of three), one flower isolate (out of one) and one seed coat isolate (out of eight) also falling into this group. An isolate from roots (one of six) reacted only with the seed isolate and no others. All other root and soil isolates did not react at all. These results would indicate that the pathogenic strains are concentrated almost exclusively in the fronds.

\section{PCR analysis}

Comparisons between the PCR primers developed by Plyler et al. (1999) and those for almost all frond isolates indicated that our isolates were all pathogenic, irrespective of the VCG they belonged to. Only three isolates did not react with the primers, interestingly these were from three different locations within Sydney and belonged to the same VCG group. Preliminary results from different parts of individual palms indicated a much higher level of pathogenicity as measured by PCR analysis than that assumed by VCG groupings with positive results occurring in soil, roots, fronds, seed coat and seed. 


\section{DISCUSSION}

Our results have shown that there is more variation in Australian isolates of $F$. oxysporum f. sp. canariensis than in those tested in Florida USA. Consequently results from Florida should not be completely correlated to the situation in Australia; the diagnostic primers developed in Florida may not necessarily work as well with Australian isolates as they do with overseas isolates. Results must be interpreted with caution and our research is ongoing.

The results with VCG have shown that the clumping of isolates by VCG and by PCR- based pathology testing do not necessarily concur. The two techniques are assessing different sections of the genome and it should be expected that differences in interpretation might occur.

These results, based on the assumption that the molecular-based pathology testing is accurate, have shown that transmission of Fusarium wilt disease could occur through transportation of infested seed. A number of bird species are known to transport the seed. However, it still remains likely that the disease will be most frequently spread by transmission of the fungus from frond to frond through pruning implements.

\section{REFERENCES}

Arai, K. and Yamagoto A., 1977. New Fusarium diseases of Canary Island date palm in Japan. Bulletin of the Faculty of Agriculture, Kagoshima University 27: 31-37.

Burgess, L.W., Summerell, B.A., Bullock, S., Gott, K.P. and Backhouse, D., 1994. Laboratory Manual for Fusarium Research, 3rd Edition. University of Sydney/ Royal Botanic Gardens, Sydney.

Mercier S. and Louvet, J., 1973. Recherches sur les fusarioses - X. Une fusariose vasculaire (Fusarium oxysporum) du palmier des Canaries (Phoenix canariensis). Annals Phytopathol. 5: 203-211.

Plyler, T.R., Simone, G.W., Fernandez, D. and Kistler, H.C., 1999. Rapid detection of the $F$. oxysporum lineage containing the Canary Island Date Palm wilt pathogen. Phytopathol. 89: (in press).

Priest, M.J. and Letham, D.B., 1996. Vascular wilt of Phoenix canariensis in New South Wales caused by Fusarium oxysporum. Australasian Plant Pathol. 25: 110-113.

Puhalla, J.E., 1985. Classification of strains of Fusarium oxysporum on the basis of vegetative compatibility. Can. J. Bot. 63: 179-183.

Simone, G.W. and Cashion,G., 1996. Fusarium wilt of Canary Island Date Palms in Florida. Landscape and Nursery Digest, May 1996: 28-31. 